\title{
Infant Birth Weight in Mothers with Maternal Anemia at Dupak Public Health Center Surabaya Working Area in 2017
}

\author{
Marisabell Giovanni ${ }^{1}$, Gwenny Ichsan Prabowo ${ }^{2}$, Widati Fatmaningrum ${ }^{3 *}$ \\ ${ }^{1}$ Faculty of Medicine, Universitas Airlangga, Surabaya, Indonesia \\ ${ }^{2}$ Department of Biochemistry, Faculty of Medicine, Universitas Airlangga, Surabaya, Indonesia - Dr. Soetomo General \\ Hospital Surabaya, Indonesia \\ ${ }^{3}$ Department of Public Health and Preventive Medicine, Faculty of Medicine, Universitas Airlangga, Surabaya, Indonesia - \\ Dr. Soetomo General Hospital Surabaya, Indonesia
}

\section{A R T I C L E I N F O}

\section{Article history:}

Received 14 May 2019

Received in revised form 24 May

2019

Accepted 26 June 2019

Available online 30 June 2019

\section{Keywords:}

Anemia,

Maternal anemia,

Low Birth Weight.

*) Corresponding author:

widatifatmaningrum@yahoo.com

\begin{abstract}
A B S T R A C T
Introduction: Anemia in pregnant women is a factor that directly affects the incidence of LBW and can be measured to determine nutritional status during pregnancy. This research is to determine the association of infant birth weight in mothers with maternal anemia at Public Health Center working area in Surabaya.

Methods: This research was a cross-sectional approach The sample of this research were 75 pregnant women at Dupak Public Health Center in Surabaya City in 2017 taken by total sampling technique. The data used was taken from the 2017 mother cohort book.

Results: The incidence of LBW at Dupak Public Health Center Surabaya working area in 2017 was 12 people (16\%). The incidence of anemia at Dupak Public Health Center Surabaya working area in 2017 was 38 people (50.7\%). The correlation between LBW and anemia in pregnancy using Chi-Square was $\mathrm{p}=0.496$.

Conclusion: There was no correlation between maternal anemia and LBW There are other factors that can affect the incidence of LBW, such as body weight and maternal height, the number of parity, a short pregnancy distance, and the existence of problems in the history of previous pregnancy and childbirth.
\end{abstract}

\section{Introduction}

Low birth weight (LBW) is an important tool to track children's health status. LBW is defined as babies who were born with a weight of fewer than 2500 grams. This case is an important problem for global public health. Some factors that can cause LBW such as maternal factors (maternal age, nutritional status, parity, the distance between pregnancy and childbirth, maternal stature), pregnancy factors (twin pregnancy and complications during pregnancy such as gestational hypertension, anemia of pregnancy, gestational diabetes, and antepartum bleeding), and fetal factors (small for gestasional age (SGA) and prematurity). Under age 20 years old, pregnant women have a risk of experiencing prolonged labour because the uterus and pelvis have not reached the adult size. Moreover, women over 35 years of age have an increased risk of pregnancy complications, perinatal morbidity, and mortality. ${ }^{1}$ Riskesdas report year of 2010 , there was a prevalence decrease from $11.1 \%$ to $10.2 \%$. In East Java province (2010) ${ }^{2}$, the LBW prevalence was below $10 \%$ and increased to more than $10 \%$ in $2013 .^{3}$ Based on the Health Profile of Surabaya in 2017, the Surabaya LBW prevalence was $2.14 \%$ of 43,992 birth babies weighed). ${ }^{1}$ LBW can affect short-term and longterm child growth and development in various organ systems. The short-term effects of LBW were the presence of respiratory distress syndrome, hyperbilirubinemia, necrotizing enterocolitis, immune system deficiency, retinopathy of prematurity, and so on. The long-term of LBW children are a higher risk of developing metabolic syndrome in adulthood such as hypertension and insulin resistance. The impact risk above was significantly increased in premature babies, born below 37 weeks, due to incomplete organ maturity when compared to term babies . ${ }^{4}$

Anemia is defined by the number and size of red blood cells or hemoglobin $(\mathrm{Hb})$ levels in the blood below the normal limit and if it is sustainable it can cause interference with the capacity of the blood to carry oxygen and distribute 
it throughout the body. Anemia can also be used as an indicator of poor nutrition and health conditions. ${ }^{5}$ Pregnant women can be said to have anemia if the $\mathrm{Hb}$ level is $<11 \mathrm{~g} / \mathrm{dl}$ in the first and third trimester or $<10.5 \mathrm{~g} / \mathrm{dl}$ in the second trimester. ${ }^{2}$ During pregnancy, the blood volume in the body can increase or experience hypervolemia on average $40-45 \%$ above the normal value of blood volume after week 32-344 Anemia in pregnant women is a factor that directly affects the incidence of LBW and can be measured to determine nutritional status during pregnancy. ${ }^{6}$ In Indonesia, the prevalence of anemia in pregnant women is included in severe health problems. Based on Riskesdas $(2013)^{3}$, anemia in pregnant women population according to anemia criteria determined by WHO and guidelines for the Ministry of Health 1999 occurred in 37.1\% of pregnant women in Indonesia, $36.4 \%$ of pregnant women in urban areas and $37.8 \%$ of pregnant women in rural areas. ${ }^{7}$

It is important to know to evaluate the specific cause of anemia and its effect on pregnancy outcomes. Anemia in pregnant women is mostly due to iron deficiency before and/ or during pregnancy. ${ }^{4}$ In spite of iron deficiency, anemia in pregnancy can also be caused by several things, such as acute blood loss and anemia due to inflammatory processes due to the development of infections, inflammatory diseases or malignancies. ${ }^{3}$ Pregnancy at a young age can also be a cause of anemia due to biological immaturity of the mother's body. Iron requirements during adolescence increase significantly due to accelerated faster growth and the start of menstruation. Moran in Demirci (2016) emphasizes that low iron stores before pregnancy in young women make them more vulnerable to iron deficiency in pregnancy and most cases have insufficient food intake. ${ }^{4}$ Anemia in pregnancy can increase the risk of LBW, preterm birth, and SGA. ${ }^{4}$ In addition, anemia is also often associated with maternal and child mortality and infectious diseases. According to WHO, anemia can cause problems in 5 global nutritional targets, there are stunting, LBW, childhood overweight, exclusive breastfeeding, and wasting. ${ }^{5}$

\section{Methods}

This study was a cross-sectional design. The subject was pregnant women at Dupak Public Health Center Surabaya from 1 January to 31 December 2017. All data obtained from the medical record. The inclusion criteria were pregnant women whose the data is fully recorded of maternal age, $\mathrm{Hb}$ level and infant birth weight and residing in Dupak Public Health Center working area. Hb levels in pregnant women were measured using the Sysmex Hematology Analyzer (Sysmex Corporation, Japan) or using the $\mathrm{Hb}$ strip. Anemia was defined if the $\mathrm{Hb}$ level is $<11 \mathrm{~g} / \mathrm{dl}$ in the first and third trimester or $<10.5 \mathrm{~g} / \mathrm{dl}$ in the second trimester3. Pregnant women are said to have severe anemia if they have $\mathrm{Hb}$ levels below $7 \mathrm{~g} / \mathrm{dl} 5$. Exclusion criteria in this study were pregnant women aged less than 20 years or more than 35 years and did not have complete data. Under age 20 years old, pregnant women have a risk of experiencing prolonged labour because the uterus and pelvis have not reached the adult size. Moreover, women over 35 years can increase the risk of pregnancy complications, perinatal morbidity, and mortality1. Data was analyzed with a Chi-Square test using SPSS for Windows, version 16.0.

\section{Results}

The total samples in this study were 75 pregnant women at Dupak Public Health Center working area in Surabaya
City who fulfill the inclusion and exclusion criteria.

As shown in table 1, the majority came from the age group of 20-24 years old (33 subjects) and the number decreased in the older age group, as seen in 25-29 years old (27 subjects), 30-34 years old (5 subjects) and 35 years old (2 subjects).

Table 1. Pregnant women based on age group

\begin{tabular}{ccccccc}
\hline \multirow{2}{*}{ Age } & \multicolumn{2}{c}{ LBW } & \multicolumn{2}{c}{ Non LBW } & \multicolumn{2}{c}{ Total } \\
\cline { 2 - 7 } & (n) & $\mathbf{( \% )}$ & $\mathbf{( n )}$ & $\mathbf{( \% )}$ & $\mathbf{( n )}$ & $\mathbf{( \% )}$ \\
\hline 20-24 years & 3 & 4 & 30 & 40 & 33 & 44.0 \\
25-29 years & 5 & 6,7 & 22 & 29,3 & 27 & 36.0 \\
30-35 years & 4 & 5,3 & 9 & 12 & 13 & 17.3 \\
35 years & 0 & 0 & 2 & 2,7 & 2 & 2.7 \\
\hline \multicolumn{1}{c}{ Total } & 12 & 16 & 63 & 84 & 75 & 100 \\
\hline
\end{tabular}

Table 2 shows that in this study it was found that majority of babies born in the Dupak Public Health Center Surabaya working area in 2017 were born within normal body weight. most pregnant women in the Dupak Public Health Center Surabaya working area in 2017 experienced anemia in their pregnancies even though the differences were not too significant. Both pregnant women who had anemia or not had the same tendency to give birth to babies without LBW (normal or high). The number of babies with LBW is found more in the group of mothers who did not experience anemia in their pregnancies than to those who had anemia in their pregnancies. Chi-square test obtained p-value was 0.496 .

Table 2. Anemia status and infant birth weight

\begin{tabular}{lccccccc}
\hline \multirow{2}{*}{ Hb } & \multicolumn{2}{c}{ LBW } & \multicolumn{2}{c}{ Non LBW } & \multicolumn{2}{c}{ Total } & \multirow{2}{*}{ P } \\
\cline { 2 - 6 } & (n) & $\mathbf{( \% )}$ & $\mathbf{( n )}$ & $\mathbf{( \% )}$ & $\mathbf{( n )}$ & $\mathbf{( \% )}$ & \\
\hline Anemia & 5 & 6.7 & 33 & 44 & 38 & 50.7 & \\
Non- & 7 & 9.3 & 30 & 40 & 37 & 49.3 & 0.496 \\
Anemia & & & & & & \\
Total & 12 & 16 & 63 & 84 & 75 & 100 & \\
\hline
\end{tabular}

Table 3. Age, Hb level, and Birth weight descriptive statistic

\begin{tabular}{lccc}
\hline & Minimum & Maximum & Mean \pm SD \\
\hline $\begin{array}{l}\text { Age (y.o.) } \\
\text { Hb level } \\
\text { (g/dL) }\end{array}$ & 20 & 35 & $25,6 \pm 4,33$ \\
$\begin{array}{l}\text { Birth weight } \\
\text { (gram) }\end{array}$ & 1000 & 4300 & $2917 \pm 611,84$ \\
\hline
\end{tabular}

\section{Discussion}

The results of this study indicate that pregnancies in the Dupak Public Health Center Surabaya working area in 2017 are dominated by the age group of 20-24 years. As age increases, the proportion of the population experiencing pregnancy decreases. The results of this study are not appropriate with the Riskesdas report (2013) data which shows that the population experiencing pregnancy in urban areas is dominated by the age group 25-29 years. However, these results are the same as the dominance of the age of the population experiencing pregnancy in rural areas. ${ }^{3}$ This 
difference in proportion can be connected to the existence of early marriage. The age at first marriage is one indicator of the start of a woman's chances of getting pregnant and giving birth. ${ }^{6}$ Marriage at a young age can be influenced by several things including low levels of education, poverty, and social and cultural norms such as gender inequality that prevail in society. ${ }^{7}$ With a young marriage age, the length of time a woman has for pregnancy and childbirth is longer6. In spite of that, pregnancy at a young age can also be a cause of maternal anemia. ${ }^{4}$ The results of Riskesdas report (2010) state that the highest age for women getting married occurs in the age group of 15-19 years. In the statistics presented, the average age of the first marriage in Indonesia is at the age of 20 years. The first marriage age in East Java Province also occurs in the age group 15-19 years with an average age of 19.6 years. ${ }^{6}$ Riskesdas report (2010) also presents data on pregnancy status at the time of the interview. Based on the age group, the results of the interviews showed that the highest pregnancies occurred in the age group of 20-24 years and 25-29 years. ${ }^{6}$ This is in line with the results of research that shows pregnancy occurs higher in younger age groups. In addition, researchers suspect that this can also occur due to seasonal population phenomena that often occur in big cities in Indonesia, one of which is Surabaya. Thus, the place of residence of the research subjects is less certain.

According to Tarwoto (2016) in Andria (2017), anemia occurs because the number of red blood cells or Hb levels decrease. ${ }^{8}$ During pregnancy, the blood in the mother's body experiences hemodilution due to an increase in blood volume averaging $40-45 \%$. Anemia that often occurs during pregnancy is iron deficiency anemia and acute bleeding. This causes the oxygen carrying capacity for maternal and fetal organs to be reduced so that it will affect the health status of mothers and babies. ${ }^{4}$

This study shows that most pregnant women in the Dupak Public Health Center Surabaya working area in 2017 are anemic. This result is in line with the research by Wijaya et.al. (2013) and Suhartati et.al. (2017) 9, 10. Different results in the study by Andria (2017) showed that most of the samples of pregnant women were not anemic. ${ }^{8}$

Based on Riskesdas report (2010), birth weight can be classified into 3 categories, namely $<2500 \mathrm{~g}, 2500-3999 \mathrm{~g}$, and $\geq 4000$ g. ${ }^{6}$ The results of Riskesdas report (2010) state that the majority of babies born in Indonesia are in the range of 25003999 g. These results also occur in the province of East Java. ${ }^{6}$ In this study, birth weight was only categorized into 2 , there were $<2500 \mathrm{~g}$ and $\geq 2500 \mathrm{~g}$. The average baby in the Dupak Public Health Center Surabaya working area in 2017 was born weighing 2917 grams. The results of this study indicate that the majority of infants in the Dupak Public Health Center Surabaya working area in 2017 did not experience LBW. In general, these results are in line with Riskesdas report (2010) and previous studies. ${ }^{8,10}$

In this study, the Chi-Square test value was 0.496 and showed that there was no relationship between anemia in pregnancy and the incidence of LBW. This result is in line with the study by Srinivas P. and Srinivasan P. (2015) which states that there is no relationship between anemia in pregnancy and LBW 11. Different results are shown by research by Andria (2017) at Rokan Hulu General Hospital, Suhartati et.al. (2017) in the Tanta District Tabalong and Wahyuning et.al. (2014) in Dr.H.Soewono Kendal General Hospital which states that there is a relationship between anemia in pregnant women and the incidence of LBW. $8,9,12$ The result of research by Budiastuti et.al. (2014) in Purwanegara Public Health Center also states that there is a relationship between anemia in trimester III pregnancy and the incidence of LBW. ${ }^{13}$ Srinivas P. and Srinivasan P. (2015) assumed that there are differences in these results because anemia experienced by pregnant women is still not too heavy, anemia in the first trimester and not in the third trimester that can affect the baby's birth weight, and possible nutritional deficiencies others that cause LBW11. KJ Kumar et.al. (2013) argued that anemia occurring in the second trimester and third trimester increased the incidence of preterm labor. In addition, anemia that occurs in the third trimester can also increase the incidence of LBW. ${ }^{14}$ It is assumed, there are factors other than anemia during pregnancy that can cause babies born with LBW.

Other factors that can affect the incidence of LBW include the age of the mother during pregnancy less than 20 years or more than 35 years, maternal posture that can be seen from the weight and height of the mother, the amount of parity, the distance of pregnancy too short, and there are problems in the history of previous pregnancies and deliveries, such as bleeding, pre-eclampsia, high fever, prolonged labor (> 12 hours), surgical delivery and stillbirth1. In this study, risk factors related to maternal age during pregnancy were excluded by making them as exclusion criteria. However, there are still other risk factors that still have possibilities. So it is necessary to do further research to analyze other factors that cause LBW incidence.

Actually, LBW can be prevented by 2 types of interventions, first to make the optimal environment for mothers to care for the fetus, like lifestyle changes during pregnancy, such as not smoking, avoiding alcohol and substance abuse, and to maximize the role of a mother as an environment for her fetus, such as do routine pregnancy checks, consume nutrients that are good for fetal growth, and if necessary taking supplements for pregnancy. ${ }^{15}$ However, in general, interventions carried out for pregnant women aim to change the environment and habits to be healthier.

In this study, the results obtained by researchers were not optimal because of weaknesses and limitations, such as the instruments used in this study is secondary data (not filled directly by researchers) so that the results obtained were not as expected because there was a lot of incomplete data.

\section{Conclusion}

This study found that there is no association between maternal anemia and the incidence of LBW in the Dupak Public Health Center Surabaya working area. This may occur because there are other factors that can affect the incidence of LBW, such as body weight and maternal height, the number of parity, the pregnancy distance that is too short, and the existence of problems in the history of previous pregnancy and childbirth.

\section{Conflict of Interest}

The author stated there is no conflict of interest

\section{References}

1. DinkesSby. Profil Kesehatan Kota Surabaya Tahun 2017. Surabaya: Dinas Kesehatan Kota Surabaya, 2017.

2. KemenkesRI. Riset Kesehatan Dasar 2013. In: RI BPdPKKK, (ed.). Jakarta: Kementerian Kesehatan RI, 2013, p. 203, 17, 24, 96. 
3. Nemeth E and Ganz T. Anemia of Inflammation. Hematology/ Oncology Clinics. 2014; 28: 671-81.

4. Demirci O, Yılmaz E, Tosun Ö, et al. Effect of Young Maternal Age on Obstetric and Perinatal Outcomes: Results from the Tertiary Center in Turkey. Balkan Medical Journal. 2016; 33: 344.

5. Talaulikar V. Anemia in Pregnancy. 2014.

6. KemenkesRI. Riset Kesehatan Dasar 2010. Badan Penelitian dan Pengembangan Kesehatan Kementerian Kesehatan RI, 2010.

7. Statistik BP, UNICEF and yang Tertunda K. Analisis Data Perkawinan Usia Anak di Indonesia. Jakarta: Badan Pusat Statistik. 2016.

8. Andria A. Hubungan Anemia Pada Ibu Hamil Dengan Kejadian Berat Badan Lahir Rendah di Rumah Sakit Umum Daerah Rokan Hulu. Maternity And Neonatal. 2017; 2.

9. Suhartati S, Hestiyana N and Rahmawaty L. Hubungan Anemia Pada Ibu Hamil dengan Kejadian Bayi Berat Lahir Rendah di Wilayah Kerja Puskesmas Tanta Kabupaten Tabalong Tahun 2016. Dinamika Kesehatan. 2017; 8: 45-54.

10. Wijaya R, Elrifda S and Noerjasin H. Hubungan Anemia Pada Ibu
Hamil dengan Kejadian Bayi Berat Lahir Rendah di Rumah Sakit Umum Daerah Raden Mattaher Jambi Periode 19 April 2013 - 31 Mei 2013. The Jambi Medical Journal. 2013; 1.

11. Srinivas $P$ and Srinivasan P. The Relationship between Maternal Anemia and Birth Weight in New Born. IOSR Journal of Dental and Medical Sciences (IOSR-JDMS). 2018; 14: 09-11.

12. Wahyuning $S$, Yati $R$ and Erawati A. Hubungan Anemia, Usia, dan Paritas dengan Kejadian BBLR di RSUD DR.H. Soewondo Kendal. Jurnal Ilmu dan Teknologi Kesehatan. 2016; 7: 30-8.

13. Budiastuti $M$ and Muhartati M. Hubungan Anemia Kehamilan Trimester III dengan Kejadian Berat Bayi Lahir Rendah di Puskesmas Purwanegara I Banjarnegara Tahun 2012-2013. Yogyakarta: Sekolah Tinggi Ilmu Kesehatan 'Aisyiyah Yogyakarta.

14. Kumar KJ, Asha N, Murthy DS, Sujatha M and Manjunath V. Maternal Anemia in Various Trimesters and its Effect on Newborn Weight and Maturity: an Observational Study. International Journal of Preventive Medicine. 2013; 4: 193.

15. Organization WH. Promoting Optimal Fetal Development: Report of a Technical Consultation. 2006. 